\title{
Outcome of supplementation of vitamin D on intact parathyroid hormone level in chronic kidney disease patients
}

\section{Adhikary LP', Khanal $A^{2}$}

'Laxman Prasad Adhikary, Associate Professor, Division of Nephrology, Department of Medicine; ${ }^{2}$ Aarjan Khanal, Resident, Department of Internal Medicine; Kathmandu Medical College Teaching Hospital, Sinamangal, Kathmandu, Nepal.

\begin{abstract}
Background: Secondary hyperparathyroidism is present in majority of patients with estimated glomerular filtrate rate less than $60 \mathrm{~mL} / \mathrm{min} / 1.73 \mathrm{~m}^{2}$. Sustained elevated parathyroid hormone level can cause osteitis-fibrosa-cystica, fracture, hypercalcemia, hyperphosphatemia, and calciphylaxis. Kidney Disease Improving Global Outcome guidelines for Chronic Kidney Disease Mineral and Bone Disorder 2017 recommends treatment with calcitriol or vitamin D analogue if parathyroid hormone level is progressively increasing and remains persistently above the upper limit despite correction of modifiable factors.

Objectives: The objective of this study was to determine the mean change in intact parathyroid hormone after calcitriol supplementation in patients with chronic kidney disease (stage 3 to 5).

Methodology: This prospective observational study enrolled 92 patients with chronic kidney disease stage 3 to 5 , not under maintenance hemodialysis. Patients who had intact parathyroid hormone level more than $200 \mathrm{pg} / \mathrm{ml}$, serum phosphate level less than $4.5 \mathrm{mg} / \mathrm{dl}$ and corrected serum calcium less than $9.5 \mathrm{mg} / \mathrm{dl}$ were selected for the study. They were supplemented with oral calcitriol $0.25 \mu \mathrm{g}$ thrice weekly for three months and intact parathyroid hormone level was measured after three months.

Results: Mean intact parathyroid hormone level before supplementation was $332.91 \pm 96.046 \mathrm{pg} / \mathrm{ml}$ and after three months of supplementation with calcitriol was $176.49 \pm 53.764 \mathrm{pg} / \mathrm{ml}$. This finding was statistically significant (Correlation: $0.471, \mathrm{p}$-value less than 0.05 ). Thus, supplementation of calcitriol reduced the mean intact parathyroid hormone level in the chronic kidney disease patients in our study.

Conclusion: Calcitriol supplementation seems to be an effective measure to reduce intact parathyroid hormone level in chronic kidney disease patients when it remains persistently high despite correction of modifiable factors.
\end{abstract}

Key words: Chronic kidney disease; Intact parathyroid hormone; Vitamin D supplementation.

DOI: https://doi.org/10.3126/jkmc.v8i2.28164

\section{INTRODUCTION}

C hronic kidney disease (CKD) is defined as the presence of kidney damage (usually detected as urinary albumin excretion of $\geq 30 \mathrm{mg} /$ day or equivalent) or decreased kidney function (defined as estimated glomerular filtration rate $[\mathrm{eGFR}]<60 \mathrm{~mL} / \mathrm{min} / 1.73 \mathrm{~m}^{2}$ ) for three or more, irrespective of the cause'.

Chronic kidney disease (CKD) is associated with mineral and bone disorder (CKD-MBD). Initially, serum fibroblast

\section{Address for correspondence}

Dr. Aarjan Khanal

Resident in Internal Medicine

Kathmandu Medical College Teaching Hospital, Sinamangal, Kathmandu, Nepal

E-mail: aarjankhanal@gmail.com growth factor 23 (FGF23) and parathyroid hormone (PTH) increase and serum calcium and phosphate remain normal. However, as the disease progresses hyperphosphatemia occurs and serum vitamin $D$ decreases ${ }^{2}$. Secondary hyperparathyroidism is present in majority of the patients with eGFR $<60 \mathrm{~mL} / \mathrm{min} / 1.73$ $\mathrm{m}^{2}$ and occurs as an adaptive response to deteriorating renal function ${ }^{3}$. Sustained elevated parathyroid hormone (PTH) levels can cause osteitis-fibrosa-cystica, fracture, hypercalcemia, hyperphosphatemia and calciphylaxis. Different observational studies have reported an increased relative risk of death in CKD stage 5 disease patients who have PTH values at the extremes, that is less than two or greater than nine times the upper normal limit of the assay ${ }^{4,5}$. 
The management of the patient with CKD involves treatment of reversible causes, slowing the progression, treating the complications and plans for possible renal replacement therapy. Drug therapy also involves adjusting drug doses with the decline of estimated glomerular filtration rate (eGFR).

According to Kidney Disease Improving Global Outcome (KIDGO) CKD-MBD guidelines 2017, if PTH remains persistently high despite correction of modifiable factors (serum calcium, phosphorus, anemia, acidosis, diabetes), treatment with calcitriol or vitamin D analogue is recommended. The 2009 KDIGO CKD-MBD guideline also summarized multiple studies demonstrating that administration of calcitriol or vitamin D analogs (such as paricalcitol, doxercalciferol, and alfacalcidol) resulted in suppression of PTH levels ${ }^{6}$. Generally, most patients who have PTH more than 2.3 to 3 times the upper limit for the assay (i.e. 150 to $200 \mathrm{pg} / \mathrm{mL}$ if upper limit for the assay is $65 \mathrm{pg} / \mathrm{mL}$ ) are treated. The preferred dose of calcitriol is $0.25 \mathrm{mcg}$ three times weekly. Calcitriol supplementation is not done if the serum phosphate is above normal range or if the corrected serum total calcium concentration is $\geq 9.5$ $\mathrm{mg} / \mathrm{dL}$ ( $\geq 2.37 \mathrm{mmol} / \mathrm{L}$ ). The reference range of the total $25(\mathrm{OH}) \mathrm{D}$ level is $20-100 \mathrm{ng} / \mathrm{mL}$ and normal range of IPTH is 10 to 55 picograms per milliliter.

The primary objective of the study was to determine the mean change in intact parathyroid hormone after calcitriol supplementation in patients with CKD (stage 3 to 5).

\section{METHODOLOGY}

The prospective observational study was conducted in Nephrology unit, Department of Medicine, Kathmandu Medical College Teaching Hospital from January 2017 to June 2017. Ethical clearance was obtained from Institutional Review Committee of Kathmandu Medical College Teaching Hospital.

\section{Sample Selection}

The following selection criteria were made for patients' enrollment:

1. Patients' with chronic kidney disease (CKD stage 3 to stage 5).

2. Intact parathyroid hormone level more than 200pg/ $\mathrm{ml}$ (3 times the normal upper limit $65 \mathrm{pg} / \mathrm{ml}$ ).

3. Serum phosphate level less than $4.5 \mathrm{mg} / \mathrm{dl}$.

4. Corrected serum calcium level of less than $9.5 \mathrm{mg} / \mathrm{dl}$.

Patients under maintenance hemodialysis were excluded from the study. Patients were enrolled in the study using non-probability consecutive sampling technique.

\section{Estimation of GFR}

GFR was estimated using the 4-variable MDRD Study equation ${ }^{7}$ controlled trial. 1628 patients with chronic kidney disease participating in the MDRD Study. Serum creatinine levels were calibrated to an assay traceable to isotope-dilution mass spectrometry. Glomerular filtration rate was measured as urinary clearance of 125I-iothalamate. Mean measured GFR was $39.8 \mathrm{~mL} / \mathrm{min}$ per $1.73 \mathrm{~m} 2$ (SD, 21.2.

$\mathrm{GFR}=175 \times(\mathrm{S} \mathrm{Cr})^{-1.154} \times(\text { age })^{-0.203} \times(0.742)($ if female $)$

GFR unit is $\mathrm{mL} / \mathrm{min} / 1.73 \mathrm{~m}^{2}$.

CKD was classified into five stages defined by the GFR and/or evidence of kidney damage, as recommended by the National Kidney Foundation ${ }^{7}$ controlled trial.1628 patients with chronic kidney disease participating in the MDRD Study.Serum creatinine levels were calibrated to an assay traceable to isotope-dilution mass spectrometry. Glomerular filtration rate was measured as urinary clearance of 125I-iothalamate.Mean measured GFR was $39.8 \mathrm{~mL} / \mathrm{min}$ per $1.73 \mathrm{~m} 2$ (SD, 21.2.

Table 1: CKD Stages

\begin{tabular}{cl}
\hline Stage & Criteria \\
\hline 1 & GFR $\geq 90$ plus evidence of kidney damage \\
2 & GFR $60-89$ plus evidence of kidney damage \\
\hline 3 & GFR30-59 \\
4 & GFR15-29 \\
\hline 5 & GFR $<15$ \\
\hline
\end{tabular}

\section{Data collection and analysis}

Data was collected from January 2017 to June 2017 (over a period of six months), after proper consent. Data were analyzed using Statistical Package for the Social Sciences version 25. Demographics including age, sex, CKD stage were included for analysis. Laboratory data regarding serum calcium, vitamin D3 level and intact parathyroid hormone level were assessed. Patients were supplemented with $0.25 \mu \mathrm{g}$ of calcitriol three times a week for 3 months. At the completion of treatment, IPTH level was measured again.

\section{RESULTS}

Out of 92 patients, the mean age of the patients was $56.35 \pm 18.68$ years, with minimum of 19 years and maximum of 93 years. $40 \%$ of them were above 65 years and $5 \%$ of the patients were below 25 years. The gender 
demography comprised of $55 \%$ male and $45 \%$ female (Table 2)

According to CKD stage of patients, $72.8 \%$ of patients had CKD stage 5, 20.7\% of them had CKD stage 4 and $6.5 \%$ of them had CKD stage 3 (Figure 1).

Comparison of means between initial IPTH and after three months of supplementation with vitamin D has been presented in table 3. Mean change in IPTH level after three months of supplementation of oral calcitriol was tested using paired t-test. Mean IPTH before supplementation was $332.91 \pm 96.046 \mathrm{pg} / \mathrm{ml}$ and after supplementation of calcitriol was $176.49 \pm 53.764 \mathrm{pg} / \mathrm{ml}$. $\mathrm{P}$-value was less than 0.05 , which revealed the significant association between IPTH and supplementation of oral calcitriol.

\section{Table 2: Socio-demographic characteristics of patients $(n=92)$}

\begin{tabular}{lcc|}
\hline Characteristics & Number & Percentage \\
\hline Age of respondents (in years) & & \\
\hline $15-24$ & 5 & 5.4 \\
\hline $25-34$ & 11 & 12.0 \\
\hline $35-44$ & 10 & 10.9 \\
\hline $45-54$ & 14 & 15.2 \\
\hline $55-64$ & 16 & 17.4 \\
\hline $65-74$ & 18 & 19.6 \\
\hline 75 and above & 18 & 19.6 \\
Mean \pm SD 53.65 \pm 18.68 & & \\
Sex of respondents & & \\
Male & 51 & 55.4 \\
Female & 41 & 44.6 \\
\hline
\end{tabular}

$(n=92)$

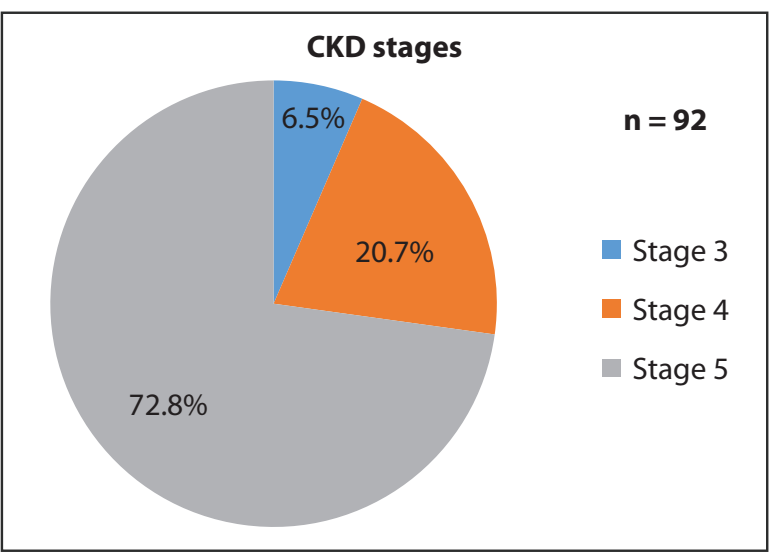

Figure 1:CKD stages of patients
Table 3: Comparing the means of IPTH $(\mathbf{n}=\mathbf{9 2})$

\begin{tabular}{lccc|}
\hline & $\begin{array}{c}\text { Mean } \\
(\mathbf{p g} / \mathbf{m l})\end{array}$ & $\begin{array}{c}\text { Std. } \\
\text { Deviation }\end{array}$ & p-value \\
\hline IPTH initially & 332.91 & 96.046 & \\
\hline IPTH after 3 months & 176.49 & 53.764 & $<0.001$ \\
\hline
\end{tabular}

\section{DISCUSSION}

The study enrolled 92 patients who fulfilled the selection criteria. They were supplemented with calcitriol $0.25 \mu$ gthrice weekly. Mean IPTH level before and after supplementation of calcitriol was analyzed. Mean IPTH before supplementation was $332.91 \mathrm{pg} / \mathrm{ml}$ and after three months of supplementation with calcitriol was $176.49 \mathrm{pg} / \mathrm{ml}$. This finding was statistically significant $(\mathrm{p}=$ $<0.001)$. Thus, supplementation of calcitriol reduced the mean IPTH level in the patients.

PTH is a major uremic toxin and is related to longterm complications like renal osteodystrophy, vascular calcifications, alterations in cardiovascular structure and function, immune dysfunction, and anemia ${ }^{8}$. Thus, timely intervention with measures to lower IPTH is of high priority to reduce the complications of secondary hyperparathyroidism. The study hereby suggests that oral vitamin $\mathrm{D}$ supplementation could be one of the interventions which can lower IPTH level in CKD patients. This study however is carried out in one treatment facility with small number of patients. Multicenter studies with large sample size are needed to conclusively establish the relation of Vitamin D supplementation with reduction of IPTH level and thereby decrease progression of CKD.

\section{CONCLUSION}

The finding of the study suggests calcitriol supplementation may be an effective measure to reduce IPTH level in chronic kidney disease (stage 3 to 5) patients. This is in congruence to the KIDGOCKDMBD guidelines 2017which recommends calcitriol supplementation if IPTH remains persistently high despite correction of modifiable factors (serum calcium, phosphorus, anemia, acidosis, diabetes).

\section{ACKNOWLEDGEMENTS}

The authors would like to thank all the patients involved for their generous cooperation during the study. 


\section{REFERENCES}

1. Levey AS, Eckardt KU, Tsukamoto Y, Levin A, Coresh J, Rossert J, Zeeuw DD, Hostetter TH, Lameire N, Eknoyan G. Definition and classification of chronic kidney disease: a position statement from Kidney Disease: Improving Global Outcomes (KDIGO). Kidney International. 2005 Jun 1;67(6):2089-100. [DOI]

2. Drüeke TB. Hyperparathyroidism in Chronic Kidney Disease. In: Feingold KR, Anawalt B, Boyce A, et al., editors. Endotext [Internet]. South Dartmouth (MA): MDText.com, Inc.; 2000.

3. Fraser WD. Hyperparathyroidism. The Lancet. 2009 Jul 11;374(9684):145-58.[DOI]

4. Floege J, Kim J, Ireland E, Chazot C, Drueke T, de Francisco A, Kronenberg F, Marcelli D, PasslickDeetjen J, Schernthaner G, Fouqueray B. Serum iPTH, calcium and phosphate, and the risk of mortality in a European haemodialysis population. Nephrology Dialysis Transplantation. 2010 Apr 25;26(6):1948-55. [DOI]
5. Fernández-Martín, J.L., Martínez-Camblor, P., Dionisi, M.P., Floege, J., Ketteler, M., London, G., Locatelli, F., Gorriz, J.L., Rutkowski, B., Ferreira, A. and Bos, W.J., 2015. Improvement of mineral and bone metabolism markers is associated with better survival in haemodialysis patients: the COSMOS study. Nephrology Dialysis Transplantation. 30(9):1542-51. [DOI]

6. Ketteler $M$, Block GA, Evenepoel $P$, Fukagawa $M$, Herzog CA, McCann L, Moe SM, Shroff R, Tonelli MA, Toussaint ND, Vervloet MG. Executive summary of the 2017 KDIGO Chronic Kidney Disease-Mineral and Bone Disorder (CKD-MBD). Kidney international. 2017 Jul 1;92(1):26-36.[DOI]

7. Levey AS, Coresh J, Greene T, Stevens LA, Zhang YL, Hendriksen S, Kusek JW, Van Lente F. Using standardized serum creatinine values in the modification of diet in renal disease study equation for estimating glomerular filtration rate. Annals of internal medicine. 2006 Aug 15;145(4):247-54.[DOI]

8. Nikodimopoulou M, Liakos S. Secondary hyperparathyroidism and target organs in chronic kidney disease. Hippokratia. 2011 Jan;15(Suppl 1):33. 